\title{
Development of the System of Legal Deposit in the U.S.S.R.
}

Mr. Whitby, formerly head, Editing and Typing Group, Cyrillic Union Catalog Section, is now subject cataloger, Subject Cataloging Division, Library of Congress.

T N THE "system of the obligatory copy," 1 or legal deposit, there has been established in the Union of Soviet Socialist Republics the legal and practical basis for collecting, listing, and distributing all printed matter. Undoubtedly more complex than the provisions for deposit elsewhere, say in the United States, France, or Great Britain, where the deposit of publications is a formality required in consequence of the granting of copyright, the Soviet system, which has no connection with copyright at all, has as its purpose the fulfillment of various library, bibliographic, archival, and statistical functions. It purports to guarantee on a continuing basis the collection of the entire mass of current publishing throughout the U.S.S.R.; it affords a solid basis for the compilation of a national bibliography $;^{2}$ in theory it ensures the steady flow of new publications to important libraries; it provides the opportunity to assemble a complete archive of Soviet publishing; and finally, the claim is made that it enables the government to compile complete statistics of publishing. The system involves a number of agencies, including printing establishments, publishing houses, the All-Union Book Chamber

\footnotetext{
1 Sistema obyazatel'nogo ekzemplyara.

2 See the author's article, "National Bibliography in the U.S.S.R.," describing the organs of national bibliography which list current Soviet publishing production, ography which list current Soviet publishing product
in the Library Quarterly, 23:16-22, January, I 953 .
}

and its affiliates, and libraries. Each of these governmental agencies has by law its assigned role to play in the system, enabling it, at least theoretically, to function smoothly according to plan.

It is the purpose of this paper ${ }^{3}$ to describe the development of this broad concept of legal deposit. While an examination of the shortcomings of the system in practice is beyond the intention and scope of this paper, it is possible, by a judicious selection of source material both legal and descriptive, to trace chronologically the development of the system under the Soviets and to present in general outline the structure of the system as it exists today.

The importance of legal deposit in Soviet Russia is clearly seen in connection with the growth of library holdings. Although the increase in publishing under the Soviets partially accounts for the large present-day collections in Soviet libraries, rationalization, namely, the system of legal deposit, plays a vital role in the acquisition policies of libraries. The All-Union Lenin Library, with more than eleven million volumes at the present time, has acquired nine-tenths of its book collection since I9I7. On the eve of the revolution the Saratov State University Library had 58,000 volumes; today its collection totals $1,227,000$ volumes.

\footnotetext{
3 The material presented here is taken in large part from the following article: Yu. V. Grigor'ev, "Sistema obyazatel'nogo ekzemplyara v SSSR za 30 let," Sovets kaya bibliografiya, IV:32'-49 (1947). An earlier article riving much the giving much the same material, although in greate detail, up to 1940 is: M. A. Godkevich, "Sovetskoye zakonodatel'stvo ob obyazatel'nom ekzemplyare," So vetskaya bibliografiya, I:78-102 (1940). Data derived from other sources are fully documented.
} 
The total size of library stocks in the U.S.S.R. is estimated at 500 million volumes, and the annual acquisition before World War II is estimated at 35-40 million volumes. The relative weight of legal deposit in the total acquisition picture may be judged from the following figures: in 1945 the All-Union Lenin Library received 33\% of its books, $16.9 \%$ of its magazines, and $73.5 \%$ of its newspapers by means of legal deposit. The Saratov State University Library in 1946 received $40 \%$ of its books on the same basis.

\section{EARLy Legislation}

The decree of the Council of People's Commissars, "On the Transfer of Bibliographic Matters in the R.S.F.S.R. to the People's Commissariat of Education," ${ }_{4}$ dated June 30,1920 and signed by Lenin, provided for the compulsory supplying of depository copies of printed matter to the most important libraries. This was the most important official pronouncement of the government dealing with the question of legal deposit. Article 4 of this decree reads :

The People's Commissariat of Education will issue compulsory regulations about the free supply of newly issued publications to national and other libraries and will specify to which libraries the free copies must be delivered.

Shortly afterwards an enactment of the Narkompros, ${ }^{5}$ "On the Compulsory Registration of Publications," 6 dated August 3, 1920, was promulgated. Article I states:

Responsibility for carrying this enactment into effect rests with the State Publishing House, and a Central Book Chamber attached to the latter should be formed for its practical realization, the necessary cost

Izvestiya VTsIK, July 9, I 920 , No. I 49.

5 Abbreviated form of Narodnyy komissariat prosveshcheniya (People's Commissariat of Education).

Izvestiya VTsIK, August 19, I920, No. I83. being charged to the State Publishing House.

According to this enactment the jurisdiction of the Book Chamber applied only to the R.S.F.S.R. ${ }^{7}$

The enactment further provided that all printing and lithographic establishments should submit 25 copies of all "publications having a literary character" 8 to certain branch agencies affiliated with the State Publishing House or Tsentropechat' ${ }^{\text {'9 }}$ and situated near the printing establishments, and that these agencies, in turn, should forward the copies to the Book Chamber for listing and distribution to the national libraries. So, instead of legal deposit being handled by the censor as in Tsarist times, a special system, directed by the Book Chamber, was founded for this purpose.

In subsequent enactments of Narkompros, the definitions of types of publications encompassed by the decree concerning legal deposit was made more precise than "publications having a literary character." The obvious kinds were covered in the first enactment. In the ruling ${ }^{10}$ of January 12, 1922, the scope of legal deposit was broadened to include appeals, mottoes, instructions, circulars, advertisements, bills, and every kind of lithographic publication. It stressed that publications "in all languages" must be presented.

It may serve a useful purpose to state here that an enactment ${ }^{11}$ of $\cdot$ the Sovnarkom ${ }^{12}$ of

7 Shortened name for Rossiyskaya Sovetskaya Federa tivnaya Sotsialisticheskaya Respublika (Russian Soviet Federated Socialist Republic), the name of the Soviet government from I9I8 to I922, when the U.S.S.R. was government from 1918 to 1922 , when the U.S.S.R. was
formed. The R.S.F.S.R exists today as one of the formed. The R.S.F.S.R. exists today
constituent republics of the U.S.S.R.

8 The enactment itemized books, pamphlets, newspapers, magazines, posters, leaflets, proclamations, pictures, portraits, postcards, maps, drawings, music publications, reports, orders, and questionnaires.

lications, reports, orders, and questionnaires. 8 , distribute periodical and non-periodical literature throughout the country.

10 Enactment of Narkompros, "O poryadke predstav leniya obyazatel'nykh ekzemplyarov proizvedeniy pechat v Rossiyskuyu tsentral'nuyu knizhnuyu palatu," January

I 2 I1 ${ }^{1922}$. G. Fogelevich. Osnovnye direktivy $i$ zakonodatel'stvo o pechati: sistematicheskiy sbornik. 6th ed. Moskva. Sovetskoye zakonodatel'stvo, 1937. pp. 167-8. 
the R.S.F.S.R., dated September 22, I925, absolved the Book Chamber of responsibility for the receipt of documents bearing security classifications.

Although the first enactment required that all publications indiscriminately be supplied in 25 copies, the number of copies of a particular work delivered in the depository manner came to be determined both by the type of publication and the quantity run off on the press. The accompanying table, illustrative of the practice for determining quantity stipulations, gives the number of publications of different types required by law ${ }^{13}$ to be delivered to the Book Chamber in 1924. Under the Soviets the number of books has been increased from an original 25 in 1920 to 48 at the present time. Modified from time to time, this method, based on formal and quantitative criteria, still obtains.

The geographic compass of the system of legal deposit also was established in the early enactments of the Narkompros and in an enactment of the All-Russian Central Executive Committee. By the latter, dated July I 7, 1922, the provisions of the previous measures were expanded to apply to all the autonomous republics and autonomous regions of the R.S.F.S.R. ${ }^{14}$ This was intended to ensure completeness in the collection of all publications issued within the R.S.F.S.R. A further tightening of the network in the R.S.F.S.R. was secured by the enactment of Narkompros of August

The libraries specified as depositories of classified ma terial included: I) Lenin Public Library, Moscow; 2) Archive of the October Revolution, Moscow; 3) State Public Library, Leningrad; 4) Library of the Communist Academy, Moscow; and 5) National Library of the Ukraine, Kiev.

12 The shortened name for Sovet narodnykh komis sarov (Council of People's Commissars). Its name was changed to Council of Ministers in 1946.

13 Enactment of Narkompros, "O predstavlenii ekzem-

13 Enactment of Narkompros, "O predstavlenii ekzem-
plyarov proizveoeniy pechati $v$ Rossiyskuyu tsentral'nuyu knizhnuyu palatu," Sobraniye uzakoneniya, i924, No 88, Art. $89 \mathrm{I}$.

14 The Soviet administrative divisions differed in I 922 from their present configuration. The R.S.F.S.R. at that time embraced areas, such as Kazakh A.S.S.R. at that time embraced areas, such as Kazakh $A$. and Kirgiz A.S.S.R., which are now full-fledged republics.
TABLE I

Publications Required by Law to be Presented to the Book Chamber in 1924 by Type and Quantity

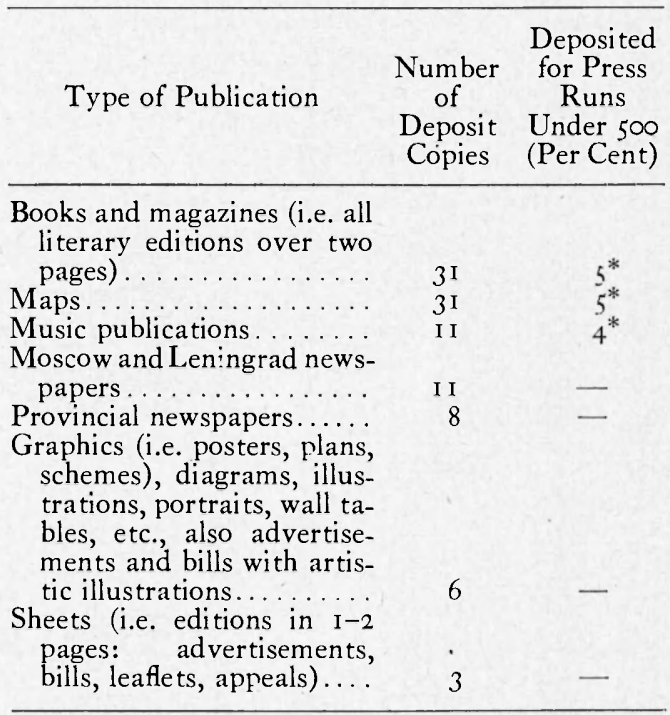

* But not less than three copies.

23, I923, which compelled publishing houses of the R.S.F.S.R. issuing publications outside the R.S.F.S.R. to submit copies of those works to the Russian Central Book Chamber. It may be added here that by this enactment the publishing houses rather than the printing establishments were made responsible for delivery. It was already the practice, established by law, for publishing houses to submit monthly lists of publications to the Book Chamber, enabling it to maintain close watch over current production. Furthermore, no publication could be released for sale or distribution by publishing houses until the Book Chamber had received its depository copies.

Other republics followed the example of the R.S.F.S.R. in establishing the legal deposit system: the Ukrainian S.S.R., March 25, I92I; the Belorussian S.S.R., September I5, I922; the Armenian S.S.R., December 27, I922; and the Azerbaidzhan S.S.R., January I 7, I923. In each case the 
Lenin decree of June 30 , I920, was used as the model for the legislation providing for the depository copies. Because no central agency comparable to the Book Chamber existed in any of the republics, publications had to be sent direct to the Russian Central Book Chamber in the R.S.F.S.R. This system contained inherent weaknesses which precluded adequate control over the delivery of the depository copies to the Book Chamber, and not until I934, by which time an organizational network of book chambers became established, was complete delivery apparently achieved.

\section{An All-Union System}

The foundation for an all-union system was laid by the statement of the Board of Narkompros, August I4, I924, entitled "Statute on the Russian Central Book Chamber." It states:

The receipt of the deposit copies of all publications issued in the territory of the U.S.S.R. should be in accordance with the corresponding decrees of the government of the R.S.F.S.R. and also on the basis of contractual agreements between the Russian Central Book Chamber and the book chambers (or substitute institutions) of the union republics.

The system of exchange, of "special agreements," between the Russian Central Book Chamber and the book chambers in the republics obtained until May 26, I928, when the Sovnarkom of the U.S.S.R. issued a resolution, ${ }^{15}$ entitled "On Supplying the Most Important National Libraries with All Publications Issued in the Territory of the U.S.S.R." This enactment, the first having all-union application, signified a broadening of legislation pertaining to the supply of depository copies to the book chambers and their distribution to libraries.

\footnotetext{
15 "O snabzhenii yazhneyshikh gosudarstvennykh knigokhranilishch vsemi izdaniyami vykhodyashchimi na territorii Soyuza SSR," Sobraniye zakonov, 1928, No. 36, Art. 324 .
}

In addition to legislation issued by the government of the U.S.S.R., there would, thenceforth, be legislation at the level of the republics in comformity with the basic law. Libraries provided for in the all-union legislation would also be covered by local enactments. This parallel legislation may seem complicated, but if it is borne in mind that the principal national libraries are provided for by the government of the U.S.S.R. while libraries important from the standpoint of the republics, as well as the libraries of allunion significance, are cared for by local legislation, then the over-all system can be clearly discerned. Another important distinction to be kept in mind relates to the statement about the number of depository copies allocated to the libraries of the U.S.S.R. at a given time. The all-union legislation is for the benefit of the "most important national libraries"; it does not designate the allotment of all the depository copies. Allocation of depository copies to other libraries is determined by legislation in the republics. In the remainder of this paper enactments both of the U.S. S.R. and the R.S.F.S.R. will be discussed side by side. Legislation of other union republics will be omitted as contributing nothing essential to the discussion.

\section{Types of Depository Copy}

The extensive geographical distribution of the depository copies, supplying both general and special libraries in the most distant regions of the Soviet Union, necessitated the creation of several new catagories of depository copies. Up to $\mathrm{I} 928$ all libraries designated as recipients of the depository copies received everything that was published without due regard for the character of individual collections. This was accomplished by means of that type of depository copy termed by the Soviets "free 
complete obligatory copy." ${ }^{16}$ This means that libraries received gratis sets of all publications in all subjects listed in the official classification scheme of the Book Chamber. ${ }^{17}$ In time, over and above the depository copies distributed to libraries free of charge in all branches of knowledge, additional depository copies were set aside for the following purposes: international exchange, stocking of special libraries, purchase, regional study, and replenishment of the collections of wardamaged libraries. These new categories for deposit will be explained in the following discussion of the enabling legislation.

On June 29, I925 an enactment of the Sovnarkom of the R.S.F.S.R. ${ }^{18}$ established a new type of depository copy for the purpose of international exchange. $\mathrm{By}$ its provisions publishing houses were directed to keep on reserve for one year a number of depository copies and to deliver them on request to the Bureau of International Book Exchange of the Russian Central Book Chamber. Later, in I939, the AllUnion Lenin Library, in lieu of the Book Chamber, became the recipient of three depository copies of each publication issued in the U.S.S.R. for the purpose of international exchange. This arrangement is in effect today, and foreign libraries interested in procuring Soviet publications are compelled to deal with the All-Union Lenin Library. ${ }^{19}$

The 1928 enactment referred to previously was of special importance because it had all-union significance. In it were listed

16 "besplatnyy polnyy obyazatel'nyy ekzemplyar."

17 At the present time this universal classification consists of 31 classes; it is used for the arrangement of bibliographic entries in the several organs of national bibliography published by the Book Chamber.

18 "O snabzhenii literaturoy Rossiyskoy knizhnoy palaty," Sobraniye uzakoneniya, I925, No. 54, Art. 399. alaty," Sobraniye uzakoneniya, I925, No. 54, Art. 399.
I9 In this connection see the revealing account of the dealings of the representative of the United States Embassy in Moscow with the officials of the All-Union Lenin Library in the following publication: U.S. Dept. of State. Cultural Relations between the United States and the Soviet Union, Pub. No. 3488, International and the Soviet Union, Pub. No. 3488, International ernment Printing Office, I949), p. 22.
I 7 national libraries located in 14 cities. $^{20}$ Depository copies on special subjects were designated for the Institute of V. I. Lenin and the Institute of K. Marx and F. Engels. Thus emerged a new type of depository copy, applying to literature in special subject fields. Previously, libraries which were recipients of the depository copies had received the copies in all the branches of knowledge as designated in the classification scheme of the Book Chamber. Thenceforth libraries could choose the publications falling within their legitimate field from parts of the classification scheme. The expression originated by the Soviet bibliographers to designate this category of depository copy is "partial depository copy." This innovation had considerable effect upon the free depository copy, which now consisted of two kinds, the complete and the partial. In general, the national depository libraries received copies of publications in all subject fields, whereas the special libraries, being interested in only certain branches of knowledge, received the partial sets.

Then in I93 I still another type of depository copy, the purchasable copy (platnyy obyazatel'nyy ekzemplyar), was introduced. An enactment dated August 23, I93 I, of the Central Executive Committee and the Sovnarkom of the U.S.S.R., states:

The compulsory supply of the leading libraries with copies of books, pamphlets, magazines, bulletins, metropolitan newspapers, music publications, maps, and plans coming out in the territory of the U.S.S.R. is worked out along lines of a purchasable as well as a free depository copy. ${ }^{21}$

This enactment meant that certain libraries could purchase depository copies at their own

${ }^{20}$ Moscow (3), Leningrad (2), Kiev, Kharkov, Ash khabad, Minsk, Baku, Tbilisi, Yerevan, Rostov-on-Don,

Kazan, Irkutsk, Tomsk, and Tashkent. knigokhranilishch vsemi izdaniyami, vykhodyashchimi na

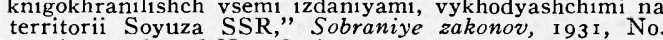
55, Art. 356, and No. 58, Art. 372 . 
expense. The types of libraries included under this enactment were general libraries not included in the list of libraries supplied gratis and special libraries of an all-union character. For the practical realization of this type of depository copy, special collectors, ${ }^{22}$ affiliated with the state publishing houses, were established. This system enabled libraries to supplement their acquisition through other channels with materials distributed by the collectors. The publishing houses held the purchasable depository copies on reserve for three months for the collectors.

A decree of the Sovnarkom of the U.S.S.R., dated September I 3, I 933, ${ }^{23}$ mentions 14 national libraries as recipients of free complete depository sets and three libraries designated to receive depository copies in special subject fields. The enactment also stated that the All-Union Lenin Library and the Government Library of the R.S.F.S.R. and the U.S.S.R. were to receive, through the book chambers of the union republics, from all institutions and organizations of the U.S.S.R. which use duplicating apparatus and which print "onesided reference material (including card indexes)," one copy each of those materials if they were not already provided by earlier enactments. Furthermore, the All-Union Lenin Library and the Saltykov-Shchedrin State Library were to be supplied with publications not included among the standard types of publications subject to deposit by existing laws. These included all remaining newspapers, posters, graphic publications, and publications for the blind. These two libraries and the press archives of the book chambers probably have the most complete collections of printed matter in the Soviet Union.

\footnotetext{
22 Tsentral'nyy kollektor nauchnykh bibliotek Kogiza. ${ }_{23}$ "O snabzhenii vazhneyshikh gosudarstvennykh knigokhranilishch izdaniyami, vykhodyashchimi na territorii Soyuza SSR," Sobraniye zakonov i rasporyazhenii
} S.S.S.R., 1933, no. 59, Art. 355 .
Under the impetus supplied by the cultural program of the Second Five-Year Plan, which called for increased book production and more libraries and reading accommodations, the number of depository copies was raised from 39 to 45 in the R.S.F.S.R. by an enactment of the Sovnarkom R.S.F.S.R., dated November 20, I 933. ${ }^{24}$ This enactment, which applied to the R.S.F.S.R. alone, was in conformity with the all-union legislation of September I3, 1933. Thus, in addition to providing for the national libraries listed in the allunion enactment, it stipulated the quantity of depository copies to be distributed among various libraries within the R.S.F.S.R. The text of the enactment states that 45 copies of all "books, pamphlets, bulletins, and other literary publications over two pages in length, and also geographic and topographic maps and plans," and 20 copies of the same publications, if less than 500 copies are printed, must be delivered to the Book Chamber. Different quantities were stipulated for other types of publications: newspapers, music publications, graphic publications, leaflet publications, publications for the blind, and processed materials. It should be pointed out that these specifications, so far as method of determination is concerned, were much the same as those established back in 1924, differing only in scope and quantity.

Other republics, too, developed their own legislation in line with the all-union enactment. While providing the Book Chamber with the required number of publications for distribution to the national libraries, the legislation contained, as in the case of the R.S.F.S.R. above, stipulations as to the number of publications to be distributed to libraries in the republics.

24 “ $\mathrm{Ob}$ obyazatel'nykh ekzemplyarakh proizvedeniy pechati, podlezhashchikh predstavleniyu v Gosudarstvennuyu tsentral'nuyu knizhnuyu palatu RSFSR," Sobraniye uzakonenii $i$ rasporyazhenii $R S F S R, " 1933$, No. 58 , Art. 269. 


\section{DECREE OF I939}

In 1935 the State Central Book Chamber was reorganized into the All-Union Book Chamber. This meant a strengthening of the organization of the book chamber network throughout the union; closer cooperation was established between the book chambers, resulting in more efficient delivery and distribution of the depository copies.

Furthermore, in 1936, the number of administrative divisions-regions (oblasti) and autonomous republics-increased; and two union republics-Kazakh S.S.R. and Kirgiz S.S.R.-were formed. This required a revision of the list of national depository libraries and a new allocation of the depository copies. The new conditions found reflection in the enactment of the Sovnarkom of the U.S.S.R. of November IO, I939. ${ }^{25}$ The salient features of this enactment, which is in effect at the present time, are: ( I ) delivery of the depository copies direct to the All-Union Book Chamber not only from the printing houses of the R.S.F.S.R., but also from the printing houses of the union republics; (2) inclusion of local minor publications in the set of depository copies supplied to the Book Chamber; (3) increase in the quantity of music publications, pictorial publications, republican and regional newspapers delivered as depository copies; (4) delivery of three copies of all publications issued by publishing houses to the All-Union Lenin Library for the purpose of exchange abroad; (5) free supply by publishing houses of 14 copies of all publications to the book office of the Communist Party; (6) the delivery of "signal" ${ }_{26}$ copies to organs of Glavlit, party

\footnotetext{
25 "O snabzhenii vazhneyshikh gosudarstvennykh knigokhranilishch SSSR izdaniyami, vykhodyashchim na territorii Soyuza SSR i o dostavke obyazatel'nykh na territorii Soyuza SSR i o dostavke obyazatel'nykh raniye postanovleniy $i$ rasproyazheniy praviltel'stva SSSR, I939, No. 57, Art. 589.

26 Although the enactment is silent as regards a definition of "signal copy" (signal'nyy ekzemplyar), the expression refers to advance copies of specially desig. nated publications. In Supplement 2 of the enactment
naterions
}

organizations, and others; and ( 7 ) distribution of the depository copy to fifteen national depository libraries. The revised list of national depository libraries included in the enactment follows:

All-Union Book Chamber, Moscow

Lenin All-Union Library, Moscow

Saltykov-Shchedrin State Public Library, Leningrad

Library of the Academy of Sciences of the U.S.S.R., Leningrad

Library of the Central Committee of the Communist Party, Moscow

State Library of the Ukrainian S.S.R., Kiev

State Library of the Belorussian S.S.R., Minsk

State Library of the Azerbaidzhan S.S.R., Baku

State Library of the Georgian S.S.R., Tbilisi

State Library of the Armenian S.S.R., Yerevan

State Library of the Uzbek S.S.R., Tashkent

State Library of the Tadzhik S.S.R., Stalinabad

State Library of the Turkmen S.S.R., Ashkhabad

State Library of the Kazakh S.S.R., AlmaAta

State Library of the Kirgiz S.S.R., Frunze

This enactment introduced still another type of depository copy-the regional copy. It was designed to strengthen bibliography and the libraries devoted to the collection of local and regional materials, and was established for the purpose of creating favorable conditions for scientific work in distant regions. It stated that all printing establishments in a given territory (kray), region

are listed the institutions and organizations which are recipients of the "signal" copy. Here are mentioned the Head of Glavlit R.S.F.S.R. (authorized to safeguard military secrets in the press), the Publishing Section of the Administration of Propaganda and A gitation, the People's Commissariat of the Interior, and the People's Commissariat of Defense. Presumably these copies are for review and censorship purposes, but whether all or only part of the printed production is included, and just when, before or after publication, the items are presented-these matters are not clear from even a close reading of the enactment. It is known that "secret" documents are not registered by the Book Chamber, or docunent to it, and it is possible that this typer, or document is covered by the provision for "signal copies." 
(oblast'), or district (rayon) should supply one copy of all publications issued by them to the library having jurisdiction over the area. This, of course, was in addition to the depository copies sent to the book chambers. This enactment empowered the Councils of People's Commissars of the union and autonomous republics to establish delivery of the local obligatory copies.

In regard to the purchasable type of depository copy, by an enactment of the Sovnarkom of the U.S.S.R., dated May 9, 1940, and entitled "On the Provision of Scientific Libraries with Purchasable Copies of Literature," all publishing houses and organizations issuing literature were each constrained to surrender to $\mathrm{OGIZ}^{27}$ of the R.S.F.S.R. I 50 copies of publications from all large printings. For printings under I OOO copies only 50 copies were required. This enactment lists the libraries to be supplied with the purchasable copies. In I 947,276 copies were required to supply scientific libraries in this manner.

\section{The War Years, I94I-I945}

The number of the free depository copies before World War II totaled 39 in the R.S.F.S.R. During the war the system of delivery was adjusted to wartime conditions. Decentralization was deemed imperative, and by order of Glavlit of the R.S.F.S.R., August 9, I94I, the disposition of the 39 depository copies was as follows: 12 to the All-Union Book Chamber, 19 direct to designated libraries, and 8 copies to remain on reserve at the printing houses for the libraries occupied by the invaders. In 1943 normal delivery and centralized distribution through the apparatus of the All-Union Book Chamber were restored. Even during the war the number of depository copies increased, so that in 1945 it came to 46 copies.

${ }^{27}$ “Ob yedeneniye gosudarstvennykh izdatel'stv" (Union of State Publisling Houses).
The number of depository copies increased to 48 after the war.

The National Fund of Literature (Gosfond literatury), attached to the Narkompros of the R.S.F.S.R., was organized in I 943 in order to restore library collections demolished during the war. Fifty-two depository copies of books, pamphlets, and magazines in the Russian, Urkrainian, and Belorussian languages were allocated to the fund. Of the I0,000,000 books collected for the fund in various ways, I, 058,000 were provided by means of depository copies.

By means of the free (complete and partial) depository copy, the purchasable copy, and the copies supplied by Gosfond, a total of 376 depository copies are reported to be distributed to libraries throughout the union. A larger figure may be obtained if to this are added the local and special depository copies for various purposes.

\section{SUMMARY}

This article has dealt with the development of the system of legal deposit as the basis for collecting, distributing, and preserving all types of printed matter in the Soviet Union. The system of legal deposit is a comprehensive system designed to provide for the complete collection of all Soviet publications in the press archives of the Book Chamber, the continuous supply of publications to a number of depository libraries situated in different parts of the country, and the compilation of a complete national bibliography. It represents one approach to a complex bibliographic problem which has not been satisfactorily solved in other countries.

In this article the most important documents pertaining to the system of legal deposit have been discussed. Legislation compelling the delivery of publications to a central office existed before 1920 , but for a variety of reasons it was ineffective. The 
first important pronouncement dealing with the question of the legal deposit of publications was the Lenin decree of 1920. All subsequent legislation derived from this fundamental decree issued by the highest governmental body in the Soviet Union, the Council of People's Commissars (now the Council of Ministers). The enactments that followed were issued by the People's Commissariat of Education and had application only in the R.S.F.S.R. The collection of publications from other union republics was secured by contracts entered into by the Book Chamber in Moscow and the book chambers or substitute organizations located in the several republics.

The enactments of the Narkompros pertained to all aspects of the depository system : the printing establishments constrained to submit publications, the type and quantity of publications required, the libraries and organizations to which the publications must be delivered, the moment when delivery was required, and the legal steps that would be taken for violation of the instructions. Some enactments were very comprehensive and went into all aspects of the delivery of the depository copies; others were only modifications of earlier enactments.

Individual republics took independent approaches to the depository copy through enactments issued by their own governmental bodies. In these instances the laws were closely patterned after the legislation in the R.S.F.S.R. There were inherent weaknesses however which adversely affected the delivery of publications to the Book Chamber in Moscow. In 1928 an allunion system was established when the Sovnarkom of the U.S.S.R. issued a resolu- tion on the supply of the most important libraries with all publications issued in the U.S.S.R. Thereafter, in addition to the enactments of the government of the U.S.S.R., there would be corresponding legislation by the republics based on the over-all enactments. The all-union legislation took care of the national library centers while the legislation of the republics had more limited applications. This is the system of legislation which obtains today.

Several different types of depository copy have been developed in the legislation of the government of the U.S.S.R. The most important are the free complete depository copy of which the national depository libraries are the recipients; the "partial" depository copy designed for libraries with special subject interests; and the purchasable depository copy which permits certain libraries to acquire whatever publications are needed.

Two significant results seem to have been attained through the instrumentality of the system of legal deposit: I) the establishment of several channels for the distribution of publications to libraries-centrally through the Book Chamber and OGIZ and locally by direct deposit in libraries; and 2) the establishment of national depositories serving as research centers in widely separated parts of the land.

The last comprehensive decree of allunion significance was issued in I939. It provides for the supply of 15 depository libraries with the free complete depository copy. As a result of the all-union legislation and the legislation of the R.S.F.S.R. the number of books delivered to the Book Chamber in Moscow is 48 at the present time. 